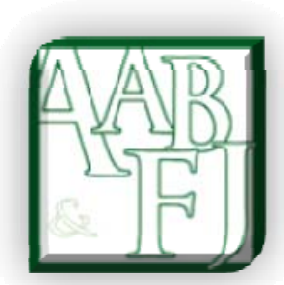

\title{
Price and Income Elasticity of Australian Retail Finance: An Autoregressive Distributed Lag (ARDL) Approach
}

\author{
Helen Higgs ${ }^{1}$ and Andrew C. Worthington ${ }^{1}$
}

\begin{abstract}
This paper models the price and income elasticity of retail finance in Australia using aggregate quarterly data and an autoregressive distributed lag (ARDL) approach. We particularly focus on the impact of the global financial crisis (GFC) from 2007 onwards on retail finance demand and analyse four submarkets (period analysed in brackets): owneroccupied housing loans (Sep 1985-June 2010), term loans (for motor vehicles, household goods and debt consolidation, etc.) (Dec 1988-Jun 2010), credit card loans (Mar 1990-Jun 2010), and margin loans (Sep 2000-Jun 2010). Other than the indicator lending rates and annual full-time earnings respectively used as proxies for the price and income effects, we specify a large number of other variables as demand factors, particularly reflecting the value of the asset for which retail finance demand is derived. These variously include the yield on indexed bonds as a proxy for inflation expectations, median housing prices, consumer sentiment indices as measures of consumer confidence, motor vehicle and retail trade sales, housing debt-to-housing assets as a measure of leverage, the proportion of protected margin lending, the available credit limit on credit cards, and the All Ordinaries Index. In the long run, we find significant price elasticities only for term loans and margin loans, and significant income elasticities of demand for housing loans, term loans and margin loans. We also find that the GFC only significantly affected the long-run demand for term loans and margin loans. In the short run, we find that the GFC has had a significant effect on the price elasticity of demand for term loans and margin loans. Expected inflation is also a key factor affecting retail finance demand. Overall, most of the submarkets in the analysis indicate that retail finance demand is certainly price inelastic but more income elastic than conventionally thought.
\end{abstract}

JEL codes: C22, D14, G01

Keywords: Retail finance demand, housing loans, term loans, credit card loans, margin loans

\footnotetext{
${ }^{1}$ Department of Accounting, Finance and Economics, Griffith University
} 


\section{Introduction}

Retail finance, also known as consumer credit or household credit, is where the payment for goods or services purchased by individuals or households directly as consumers is not at the moment of purchase, but rather takes the form of repayments over a period under some prearranged payment plan. This general definition therefore encompasses financing activities as diverse as non-revolving credit loans-for the purchase of new and existing houses and land, motor vehicles, debt consolidation, household appliances, furnishings and other durable goods and holidays - and revolving credit loans, again for the purchase of durable goods, but also nondurable goods and services of all types, debt refinancing and margin lending.

In Australia, as elsewhere, retail finance thus represents a significant amount of the financial resources available in the economy and thereby an important determinant of household economic and social welfare. For example, in 2009-10, secured finance commitments to individuals totalled $\$ 180$ billion for the purchase of new and existing dwellings and \$5 billion for alternations. At the same time, personal finance commitments amounted to $\$ 371$ billion for the purchase of new and used motor vehicles, \$25 billion for household and other personal goods and services, \$17 billion for debt consolidation, along with revolving credit facilities of $\$ 3,462$ billion.

Clearly, a sound understanding of the demand for retail finance is then of importance for several parties for a number of reasons. These include, among others, the macro impact of consumer credit on the interest rate transmission channel of monetary policy for central bankers, on micro uses by regulators for assessing financial stability, and for industry users seeking to understand the evolution of credit markets and the impact of credit demand on purchasing behaviour. One particular focus here is the price and income elasticities of demand and how changes in prices and incomes, among other things, affect the demand for the different components of retail finance.

The needs of those interested in better understanding the conditions of retail finance demand also change over time, often rapidly. For instance, for most of the 1990s and 2000s, household debt in Australia (as in most developed economies) grew significantly, driven by surging housing prices, buoyant stock markets, and brisk innovation in consumer goods markets. Given the 2007-11 Global Financial Crisis (GFC), these same economies are now experiencing slowing credit demand if not rapid deleveraging, with households increasingly reining in consumption and saving more than ever. For example, during the most recent quarter, in seasonally adjusted terms the total value of owner-occupied housing commitments excluding alterations and additions in Australia fell 4.6\%, while personal revolving credit commitments fell by $14.5 \%$ and fixed lending commitments by $4.5 \%$. This has important implications for future economic recovery.

Unfortunately, despite the patent need for a sound understanding of retail finance demand, there is no known academic study in Australia that examines these important issues. Elsewhere, an emerging literature employing both macro and microanalyses is in evidence. Accordingly, the purpose of this paper is to estimate demand equations for retail finance. The main novelties of our work are twofold. First, we use aggregate data over a relatively long period in conjunction with advanced time-series techniques. We particularly focus on the price and income elasticities of demand and the impact of the GFC on the dynamics of retail finance markets. Second, while some lending submarkets have been intensively examined overseas (but not in Australia), such as home loans, far fewer studies concern the demand for non-revolving credit items like term loans, and even fewer concern forms of revolving credit like credit cards and margin loans. In response, we estimate separate demand functions for owner-occupied housing loans, term loans, credit card loans and margin loans.

The remainder of the paper comprises five sections. Section 2 discusses the estimation approach and Section 3 presents the variable specification. Section 4 details the models 
estimated and Section 5 provides the results. The paper ends with some concluding remarks in Section 6.

\section{Estimation approach}

The method we employ to estimate the price and income elasticity of retail finance in Australia is to specify the demand (as measured by consumption) of four types of retail finance as regressands and indicator rates, and household income and other factors as regressors using the bounds test and autoregressive distributed lag (ARDL) cointegration procedure developed by Pesaran et al. (2001). Recent empirical applications in a variety of contexts include De Vita and Abbott (2004), Narayan (2005), Narayan and Smyth (2005), Fosu and Magnus (2006), Tang (2007) and Pahlavani and Rahimi (2009). This technique has three main advantages over earlier cointegration techniques when applied to the aggregate data in our study. Firstly, it is relatively simple compared with the Johansen and Juselius (1990) multivariate cointegration technique as ARDL permits the cointegration relationship to be estimated using ordinary least squares (OLS) once we identify the lag order of the model.

Secondly, the chosen approach is applicable irrespective of whether the regressors are purely stationary without any trend — and thus integrated of order zero or I(0)] — or with a unit root (a random walk), and therefore either integrated of order one or I(1)] or mutually cointegrated. Nevertheless, it will produce spurious results for I(2) or higher series so differencing is still required to reduce these to I(1). Finally, the technique is more efficient for the small sample size found with our data, a situation where both the Engle and Granger (1987) and Johansen $(1988,1991)$ cointegration methods are considered unreliable.

The ARDL including bounds test comprises three steps. The first step is to estimate a standard log-log specification of the cointegrating long-run relationship for an I(1) dependent variable as a function of a vector of $\mathrm{I}(d)$ regressors of order $0<d<1$.

\section{Variable specification}

Four separate retail finance demand equations are estimated. Table 1 provides details of the dependent and independent variables in each equation, including the sources of the data, the number of quarterly observations and selected descriptive statistics.

The first retail finance submarket examined is owner-occupied housing loans (HSE). In terms of independent variables, we measure the price of housing loans (HPR) with the standard variable bank mortgage rate while annual full-time earnings (INC) measure income. We expect the signs on the estimated coefficients for these regressors to follow those expected for a normal good with a downward sloping (inelastic) demand curve (because of limited substitution opportunities) and demand increasing positively, but less than proportionately, with income (neither an inferior nor superior good). In addition, we include the yield on indexed bonds (INB) as a proxy for expected inflation. All other things being equal, higher expected inflation brings forward purchases of the underlying asset and with it finance consumed based on this asset. A positive coefficient is hypothesised.

We make identical assumptions for each of the remaining three dimensions of retail finance considered in this analysis (terms, credit card and margin loans), such that the expected estimated price elasticity and income elasticity will be negative and positive, respectively, and the estimated coefficient on expected inflation is positive. Moreover, we expect the price elasticity of demand to be inelastic (the quantity demanded changes less than proportionately given a change in prices) so that the estimated coefficient will be less than one (negative). In comparison, income elasticity should lie in the range zero to one indicating 
a less than proportionate change in borrowing with a change in income (negative for an inferior good and more than one for a superior good).

For housing loans, we include several additional demand factors specifically related to thr overall housing market and housing finance conditions. These are debt-to-housing assets (DTA) as an indicator of leverage (and financial flexibility), for which we expect a positive coefficient, and housing interest payments-to-disposable income (RTD) as a measure of debt servicing requirements, for which we expect a negative coefficient associated with increasing mortgage stress. We also include the median housing price $(M H P)$ to reflect the price level of the underlying asset, for which we expect a positive coefficient. As all of the above data have been collected over the longest period, we are able to obtain 100 quarterly observations for each variable, beginning in September 1985 and ending in June 2010.

The second submarket of retail finance demand is term loans, comprising loans for motor vehicles, household goods, debt consolidation, etc. We measure the quantity demanded with the amount of fixed term lending commitments $(T L N)$ and again specify the price with an indicator lending rate, but this time for fixed term loans (TPR), income with full-time earnings (INC) and the impact of expected inflation with the yield on indexed bonds (INB). As discussed we expect similar signs as above for the estimated coefficients for price (-), income $(+)$ and expected inflation $(-)$. However, as the demand for term loans most closely aligns with conditions in retail goods markets for which the demand for finance is a derived demand, we also include the volume of retail trade (RET) and motor vehicle sales (MVS), along with the Westpac-Melbourne Institute consumer sentiment index (CMS) as an indicator of consumer confidence. We expect positive coefficients when we specify these additional demand factors as regressors. Unfortunately, data are available on some of these variables for only a shorter period than housing loans so we are only able to obtain 87 quarterly observations, again ending in June 2010 but commencing somewhat later in December 1988.

The third submarket of retail finance demand is credit card lending, with the quantity demanded proxied by the amount of credit used at the end of each quarter (CCS), the price with the indicator rate for standard credit cards (CCP), income with annual full-time earning (INC) and expected inflation with the yield on indexed bonds (INB). The expected signs on the estimated coefficients are again as above. In addition, we include the credit limit at the end of the quarter $(C P R)$ to represent the theoretical borrowing limit. All other things being equal, the amount borrowed should increase alongside the facility for borrowing. As with terms loans, we include the value of retail trade (RET) and the consumer sentiment index (CMS) to proxy for the impact of retail sales and consumer confidence on credit card-related purchases. We again expect the last two variables to display positive coefficients when they serve as regressors for credit card loans. The maximum data period available here is slightly shorter than for terms loans, so we obtain 82 quarterly observations, starting in March 1990 and ending in June 2010.

The final submarket of retail finance demand is margin loans, defined as the aggregate value of outstanding loans backed by approved securities (usually Australian equities and managed funds). The data are from a survey of banks and brokerage firms offering marginlending facilities, with market coverage of at least 95\%. Margin loans are the most common way that Australian households borrow to invest in equities. They typically involve the borrower lodging cash, shares or managed funds with the lender, which then provides a line of credit-the margin loan - to purchase additional shares and managed funds, which then also become security for the loan. The collection of most of the variables defined here has been only over for a relatively short period, so we are able to specify just 40 quarterly observations, starting in September 2000 and ending in June 2010. The dependent variable is the amount of margin lending $(M L N)$ with the yield on indexed bonds (INB) and annual full- 
time earnings (INC) again proxying for the effect of expected inflation and income. We use the indicator rate on margin loans $(M P R)$ to represent the price of margin loans.

We include an additional four factors of demand specific to margin loans. The first of these is the proportion of protected margin lending $(P R P)$. This refers to margin loans packaged with a derivative product that guarantees that the capital value of the underlying portfolio does not fall. Lenders typically charge a higher rate of interest for providing a capital protection facility. We expect a positive coefficient when margin lending is regressed against the proportion of protected margin lending, reflecting that borrowers face less risk when using these facilities and are therefore more likely to draw down margin loans. The second additional demand factor for margin lending is the proportion of lending-to-aggregate credit limit (PLA). The aggregate credit limit is the sum of the approved loan limits of lenders, and therefore represents the total amount lenders are willing to lend under margin loans. Naturally, we expect the amount of margin lending to increase alongside the aggregate credit limit. We again hypothesise a positive coefficient.

The third additional demand factor for margin loans is the proportion of the aggregate credit limit-to-value of underlying security $(P A S)$. The value of the underlying security is the market value of all securities backing the margin lending at the end of the quarter, so we expect margin lending in aggregate will increase with the value of the underlying security. The final additional demand factor for margin loans is the ASX All Ordinaries Index (ASX). This is a proxy for market conditions relating to the current and expected value of the underlying security so we again expect a positive coefficient.

The final variable addresses the key focus in this study of the 2007-2011 GFC and its impact on the price and income elasticity of retail finance demand. In brief, from a retail perspective, the period leading up to the GFC is characterised by increasing household debt burden and over-leveraging, the growth of retail financial flexibility, innovation, and complexity, the apparent mispricing of retail finance risk and burgeoning levels of household wealth associated with strong financial and housing markets. In contrast, the period during and after the GFC is exemplified by deteriorating conditions in housing markets and housing finance, declines in overall economic activity and certainty, falling consumer wealth, and a marked deterioration in consumer confidence. To reflect these changes we define a dummy variable for the GFC and post-GFC environment that takes a value of one for all quarters from March 2008 to June 2010, otherwise zero. We employ this dummy variable as both a constant and as an interaction variable with the price and income elasticities of demand for each of the retail finance submarkets.

\section{Model specification}

For each retail finance submarket, we specify the following equation:

$$
\begin{aligned}
\Delta \ln Y_{t}= & \alpha_{0}+\alpha_{1} \ln Y_{t-1}+\alpha_{2} G F C_{t} \times \ln \text { Price }_{t}+\alpha_{3} G F C_{t} \times \ln \text { Income }_{t}+\sum_{i=4}^{m+3} \alpha_{i} \ln X_{i t-1} \\
& +\alpha_{m+4} \Delta \ln Y_{t-1}+\alpha_{m+5} G F C_{t} \times \Delta \ln \text { Price }+\alpha_{m+6} G F C_{t} \times \Delta \ln \text { Income } \\
& +\sum_{i=1}^{m} \sum_{j=1}^{p} \alpha_{i j} \Delta \ln X_{i t-j}+\alpha_{m+7} G F C_{t}+\varepsilon_{t}
\end{aligned}
$$

where $Y$ is loans in each of the retail finance submarkets (HSE, TLN CCS and MLN), $\alpha_{0}$ is drift, $\alpha_{1}$ is an autoregressive parameter, $\alpha_{2}, \alpha_{3}, \alpha_{\mathrm{i}}$ are long-run multipliers for the explanatory variables, Price is respectively $H P R, T P R, C P R$ and $M P R$, Income is $I N B, X_{i t-i}$ is $i=4$, $3, \ldots . m+3$ where $m$ is the number of explanatory variables, $\Delta$ are first-differenced terms to 
ensure the residuals, $\varepsilon_{\mathrm{t}}$, are white noise identically and independently distributed (i.i.d), $\alpha_{\mathrm{m}+\mathrm{i}}$ $\mathrm{i}=4,5,6$ and $\alpha_{i j}$ are first-differenced parameters where $p$ is the number of lags, $\alpha_{m+7}$ is the estimated coefficient for the dummy variable, GFC, and all other variables are as previously defined.

Equation (1) is estimated by OLS in order to test for the existence of a long-run relationship among the lagged levels of the explanatory variables by conducting a joint $F$-test to determine the significance of the coefficients of these slope variables. The null hypothesis of no cointegration among the variables in Equation (1) is tested using $\mathrm{H}_{0}: \alpha_{1}=\alpha_{2}=\alpha_{3}=\alpha_{4}$ $\ldots .=\alpha_{m+1}=0$ against the alternative $\mathrm{H}_{1}: \alpha_{1} \neq \alpha_{2} \neq \alpha_{3} \neq \alpha_{4} \ldots \neq \neq \alpha_{m+1} \neq 0$. Two sets of critical values reported in Pesaran et al. (2001) provide critical values bounds of the test for cointegration, when the explanatory variables are assumed $\mathrm{I}(d)$ where $0<d<1$. The lower critical value of the bounds test assumes the regressors are $\mathrm{I}(0)$ and the upper value assumes the regressors are I(1). If the F-statistic is above the critical upper limit, then the null hypothesis of no cointegrating long-run relationship can be rejected, irrespective of the orders of integration of the individual time series. Conversely, if the F-statistic is below the lower critical value, then the null hypothesis of no cointegrating long-run relationship cannot be rejected. If the $F$-statistic falls between these critical values, the test is inconclusive.

In the second step, once cointegration has been established the conditional ARDL (1, $p$ lags for each explanatory variable) long-run model for the log of $Y$ is estimated in Equation (2) as:

$$
\ln Y_{t}=\beta_{0}+\beta_{1} \ln Y_{t-1}+\beta_{2} G F C_{t} \times \ln \text { Price }_{t}+\beta_{3} G F C_{t} \times \ln \text { Income }_{t}+\sum_{i=1}^{m} \sum_{j=0}^{p} \beta_{i j} \ln X_{i t-j}+\beta_{4} G F C_{t}+\varepsilon_{t}
$$

This involves selecting the orders of the ARDL (1, $p$ lags for each explanatory variable) model using the Akaike information criteria (AIC). The third and final step involves the estimation of the short-run dynamic parameters using the error correction model (ECM) associated with the long-run estimates. The ECM is defined in Equation (3) as follows:

$$
\begin{aligned}
\Delta \ln Y_{t}= & \gamma_{0}+\gamma_{1} \Delta \ln Y_{t-1}+\gamma_{2} G F C_{t} \times \Delta \ln \text { Price }_{t}+\gamma_{3} G F C_{t} \times \Delta \ln \text { Income }_{t}+\sum_{i=1}^{m} \sum_{j=1}^{q} \gamma_{i j} \Delta \ln X_{i t-j} \\
& +\gamma_{4} E C R_{t-1}+\varepsilon_{t}
\end{aligned}
$$

where $\gamma_{\mathrm{ij}} i=1,2,3, \ldots \mathrm{m}, j=1,2 \ldots q$ are the short-run dynamic coefficients of the convergence of the model to equilibrium and ECR is the speed of adjustment. Note that as GFC is by nature long run (fixed from March 2008 to June 2010) we do not include it as a constant in the ECM, though we retain its short-run interactions with the price and income variables.

\section{Empirical results}

The ARDL bounds test for cointegration used in this study does not depend on pre-testing the order of integration. Nonetheless, a unit root test is conducted on all variables as the procedure does require that all variables are either $\mathrm{I}(0)$ or $\mathrm{I}(1)$. We employ a relatively more efficient autoregressive univariate Dickey-Fuller generalised least squares (DF-GLS) unit root test (Elliot et al. 1996). This is a modification of the augmented Dickey-Fuller (ADF) unit root $t$-test with the application of generalised least squares (GLS) which de-trends the series before applying the ADF test. In general, the DF-GLS test outperforms the ADF test in relation to sample size and power. The DF-GLS test includes a constant and trend for the log level series and a constant with no trend for the difference of the log level series. In Table 2, 
we present the DF-GLS unit root tests and the critical values for each set of variables in the four demand equations. Note that even though some variables are the same across all (INB and $I N C$ ) or some (RET and CMS) of the four demand equations, the critical values for the unit root tests will vary according to the number of observations available. For the most part, while some series are stationary in levels or I(0), nearly all variables are stationary in firstdifferences or I(1). This indicates that the data is suitable for applying the ARDL procedure.

In order to conduct the bounds test for cointegration, the first step taken in the ARDL procedure is to test for the log-run relationship in Equation (1). We employ a maximum lag order of one given the relatively large number of explanatory variables and the short sample period. Equation (1) is estimated using OLS regression. The joint F-test is conducted on the lagged log-level variables while the differenced variables have no direct influence on the bounds cointegration test (Pesaran and Pesaran 1997). The F-statistic tests the joint null hypothesis that the coefficients of the lagged log-levels are equal to zero which implies that no cointegrating long-run relationship exists. The calculated $F$-statistic for housing loans (HSE) is 1.86 which is lower than the simulated upper bound critical value for $k=9$ and $n=$ 78 with unrestricted intercept and trend at the .07 level of significance. As this falls in the inconclusive region, we are unable to reject the null hypothesis of no cointegration, indicating that a long-run cointegrating relationship may not exist between the dependent and explanatory variables in this model. With terms loans, credit card loans and margin loans, the respective calculated F-statistics of 2.47, 3.68 and 3.75 are higher than the upper bound critical values for $\mathrm{k}=9,9$ and 10 and $\mathrm{k}=65$, 60 and 16, respectively, with unrestricted intercepts and trends at the .02, .01 and .01 levels of significance. Accordingly, in these cases, we conclude the presence of a long-run cointegrating relationship. That is, the variables tend to move together, or at least not too far apart, over time.

The second step of the ARDL procedure is to estimate the long-run model for the logs of $H S E, T L N, C C S$, and $M L N$ in line with Equation (2). This equation is estimated using the ARDL $(1,0,0, \ldots 0)$ specification according to the AIC criterion of optimal lag selection. We specified various lags in the models with the aim of optimising the overall goodness-of-fit of each model. Table 2 presents the results with the long-run estimated coefficients, standard errors and p-values in columns 2-4 for HSE in the first panel, TLN in the second panel, CCS in the third panel and MLN in the fourth panel. Consider the results for HSE. Other than lagged HSE (which indicates a $69.4 \%$ probability of a one-quarter increase in housing loans being followed by another) three explanatory variables exert a significant (10\% or lower) effect on housing loans in the long run: namely, INB, $M P H$ and INC.

In terms of the main focus of the analysis, the price of housing loans (HPR) is not a significant demand factor in the long run, whereas the income elasticity (INC) of 1.46 is significant and positive in line with expectations, suggesting housing is not strictly a normal good (demand changes more than proportionately with income). Inflation expectations (INB) are significant and consistent with our expected sign, such that a $1 \%$ increase in expected inflation (INB) leading to a $0.27 \%$ decrease in HSE (reduced demand for housing loans). The coefficient for median housing prices (MHP) is also significant, but does not display the expected positive sign. The estimated coefficient here indicates that a $1 \%$ increase in median housing prices $(M H P)$ reduces the demand for housing loans by $0.44 \%$. Interestingly, neither the constant nor the interactions terms for GFC are significant, thereby indicating that the GFC has had no significant effect on long-run housing loan demand at the aggregate level. Overall, the model is highly significant, with an R2 of 0.99 and the F-statistics of 1055.19 rejecting the null hypothesis of the joint insignificance of the slope coefficients at the .01 level.

Now consider the demand for term loans shown in the second panel of Table 3. As shown, four factors (other than lagged terms loans indicating a probability of $72.2 \%$ of a one- 
quarter increase in terms loans being followed by another) are significant in the long-run: $T P R$ (the price of terms loans), INB (inflation expectations), GFC x INC (the interaction of the GFC with income) and GFC (as a constant). The estimated coefficient for TPR as the price of terms loans is significant and negative indicating that terms loans are indeed price inelastic (the quantity demanded changes less than proportionately with a change in price). We can also see that a $1 \%$ increase in expected inflation is associated with a decrease in the terms loans of $.10 \%$. As for the impact of the GFC, there is strong evidence of an overall decrease in demand for term loans because of the GFC (-15.461, p-value $=0.021)$. There is also the suggestion that income, which is not typically a significant factor, has become significant with the interaction term, such that during and after the GFC term loans have become a superior good (demand increasing more than proportionately with income). Once again, the model is highly significant and accounts for $98.41 \%$ of the variation in terms loans over the sample period.

The estimated results for credit card loans are in the second panel of Table 3. Only a single demand factor other than lagged credit card loans is significant in the long run, namely, the credit limit at the end of the previous quarter $(C C P)$. The value of -0.172 indicates that a $1 \%$ increase in the credit card limit is associated with a $0.17 \%$ decrease in credit usage. The overall model is again strongly jointly significant and explains $99.9 \%$ of the variation in credit card use, while there is not a statistically significant price or income effect with credit card usage at the aggregate level, nor any impact of the GFC, in the long run.

The final long run demand model in Table 3 is for margin loans (MLN). We first can see that the probability of a one-quarter increase in margin loans being followed by another is $34.3 \%$. We can also see that aggregate margin loans exhibit a significant and positive price effect of -0.418 (price inelastic) and are highly income elastic (2.487) (a superior good). Other significant demand factors for margin loans are the positive impacts of the proportion of aggregate lending-to-aggregate credit limit (PLA), the proportion of aggregate credit limitto-value of the underlying security (PAS), and the ASX All Ordinaries Index (ASX). All other things being equal, a $1 \%$ in aggregate lending-to-aggregate credit limit will increase margin loans by $0.83 \%$, a $1 \%$ increase in aggregate credit limit-to-value of the underlying security will increase margin loans by $0.48 \%$, while a $1 \%$ increase in the ASX All Ords will increase margin loans by $0.74 \%$. Importantly, we can evidence the highly detrimental effect of the GFC on the demand for margin loans with the interaction of GFC with income elasticity being highly significant and negative, suggesting that while before the GFC margin loans were a superior good, during and after the GFC they are a inferior good (quantity of demand falling with an increase in income).

The third and final step of the ARDL procedure is to estimate the short-run dynamic coefficients associated with the ECM from the long-run relationship as specified in Equation (3). The results are in columns 6-8 in Table 2 with those for HSE in the first panel, TLN in the second panel, CCS in the third panel and MLN in the fourth panel. We first consider the overall fit and dynamics of both models. First, the long-run models are clearly better able to explain the variations in retail finance demand than the short-run models, with the HSE model explaining $41.05 \%$ of the variation in housing finance demand in the short run (compared to $99.17 \%$ in the long run), TLN explaining $31.73 \%$ of variation in the short run and $98.84 \%$ in the long, CCS $64.59 \%$ of variation in the short run and $99.99 \%$ in the long run. The only possible exception is the demand function for margin loans where the model explains $94.6 \%$ of the variation in the short-run model and $99.72 \%$ in the long run. Second, the estimated error correction coefficients (ECR) of -0.689 for the HSE mode, -0.745 for the TLN model, -0.704 for the CCS model and -1.128 for the MLN model are significant at the $1 \%$ level of significance. These indicate the high speed of adjustment to equilibrium after a 
shock: that is, most of the deviation in the demand factors from a previous quarter's shock converges back to the long-run equilibrium in the current quarter.

We now focus on the differences in the estimated coefficients in the long and short-run models for each type of retail finance demand, starting again with housing loans (HSE). Once again, apart from the lagged value of housing loan demand, expected inflation (INB) has a significant negative effect on the demand for housing loans in the short run. The only other significant factor is housing interest payments-to-disposable income (debt servicing). There is again no significant short-run price while the income effect that was significant in the long run is no longer significant. There is also no significant short-run effect of the GFC on the demand for housing loans at the aggregate level, either in itself or through changes in the price or income elasticity of housing loan demand.

For term loans in the short run $(T L N)$, we can see that the GFC has made the price elasticity of demand for term loans even more inelastic, while the demand for term loans is strongly positively associated with retail trade such that a $1 \%$ increase in retail trade is associated with a $1.51 \%$ increase in the demand for term loans. Expected inflation (INB) remains a significant demand factor in the short run while there is no obvious impact of the GFC. The income elasticity of term loans is no longer significant. With credit cards, the only significant coefficient other than lagged credit card loans is the price of credit card loans $(C P R)$, with the indication that credit cards are price inelastic in the short run but that the demand for credit card loans is largely unresponsive to the price of these loans in the long run.

Finally, with margin loans $(M L N)$ we can see that $P L A, P A S$ and $A S X$ remain significant in the short run as in the long run. The proportion of protected margin lending $(P R P)$ is now significant in the short run, suggesting that the presence of this facility increases the demand for margin loans. As for price elasticity, no significant effect is found except since the GFC when the price elasticity of demand has become significantly more elastic (positive). Income elasticity is also positive and highly elastic in the short run as in the long run, though the significant negative value on income elasticity since the GFC suggests that margin loans have become somewhat less income elastic.

\section{Conclusion}

This paper uses the ARDL procedure to model demand equations for four submarkets of retail finance: housing loans, terms loans, credit card loans, and margin loans for various sample periods up to 25 years and until June 2010. Panel unit root tests are used to indicate that all of the quarterly series in the analysis are either stationary in levels or I(0) or in firstdifferences or I(1). The bounds testing procedure for cointegration subsequently finds longrun cointegrating relationships in all models except for housing loans where the results are marginally inconclusive.

In the long run, we find significant price elasticities only for term loans and margin loans, and significant income elasticities of demand for housing loans, term loans and margin loans. We also find that the GFC has only significantly affected the long-run demand for term loans and margin loans. In the short run, we find that the GFC has had a significant effect on the price elasticity of demand for term loans and margin loans, with only credit card loans exhibiting a significant price elasticity of demand otherwise. Expected inflation is also a key factor affecting retail finance demand. Overall, most of the submarkets in the analysis indicate that retail finance demand is price inelastic but more income elastic than conventionally thought. 


\section{References}

De Vita, G \& Abbott, A 2004, 'Real exchange rate volatility and US exports: An ARDL bounds testing approach', Economic Issues, vol. 9, no. 1, pp. 69-78.

Elliott, G, Rothenberg, TJ \& Stock, JH 1996, 'Efficient Tests for an Autoregressive Unit Root', Econometrica, vol. 64, no. 4, pp. 813-836. http://dx.doi.org/10.2307/2171846

Engle, RF \& Granger CWJ, 1987, 'Co-integration and error correction: Representation, estimation, and testing', Econometrica, vol. 55, no. 2, pp. 251-76. http://dx.doi.org/10.2307/1913236

Fosu, OE \& Magnus, FJ 2006, 'Bounds testing approach to cointegration: An examination of foreign direct investment trade and growth relationships', American Journal of Applied Science, vol. 3, no. 11, pp. 2079-2085. http://dx.doi.org/10.3844/ajassp.2006.2079.2085

Johansen, S 1988, 'Statistical analysis of cointegrating vectors', Journal of Economic Dynamics and Control, vol. 12, no. 2-3, pp. 25-31.

Johansen, S 1991 'Estimation and hypothesis testing of cointegration vectors in Gaussian vector autoregressive models’, Econometrica, vol. 59, no. 6, pp. 1551-1580. http://dx.doi.org/10.2307/2938278

Johansen, S \& Juselius. K 1990, 'Maximum likelihood estimation and inferences on cointegration with applications to the demand for money', Oxford Bulletin of Economics and Statistics, vol. 52, no. 2, pp. 169-210. http://dx.doi.org/10.1111/j.14680084.1990.mp52002003.x

Narayan, PK 2005, 'The saving and investment nexus for China: Evidence from cointegration tests', Applied Economics, vol. 37, no. 17, pp. 1979-1990. http://dx.doi.org/10.1080/00036840500278103

Narayan, PK \& Smyth, R 2005, 'Trade liberalization and economic growth in Fiji: An empirical assessment using the ARDL approach', Journal of the Asia Pacific Economy, vol. 10, no. 1, pp. 96-115. http://dx.doi.org/10.1080/1354786042000309099

Pahlavani, M \& Rahimi, M 2009 'Sources of inflation in Iran: An application of the ARDL approach', International Journal of Applied Econometrics and Quantitative Studies, vol. 6, no. 1, pp. 61-76.

Pesaran, MH \& Pesaran, B 1997, Working with Microfit 4.0: Interactive Econometric Analysis Oxford University Press, Oxford.

Pesaran, MH, Shin, Y \& Smith, RJ 2001 'Bounds testing approaches to the analysis of level relationships’, Journal of Applied Econometrics, vol. 16, no. 3, pp. 289-326. http://dx.doi.org/10.1002/jae.616

Tang, TC 2007, 'Money demand function for Southeast Asian countries An empirical view from expenditure components', Journal of Economic Studies, vol. 34, no. 6, pp. 476496. http://dx.doi.org/10.1108/01443580710830952 
AABFJ | Volume 8, no. 1, 2014

TABLE 1 Variable descriptions and selected descriptive statistics

\begin{tabular}{|c|c|c|c|c|c|c|c|c|c|c|c|}
\hline Finance & Variable & Description & Source & Start & End & Obs. & Min. & Max. & Mean & Std. dev. & $\mathrm{CV}$ \\
\hline \multirow{7}{*}{ 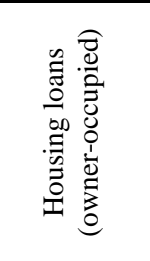 } & HSE & Housing finance commitments for owner-occupation (\$m) & ABS & Sep-85 & Jun-10 & 100 & 2304.89 & 52234.41 & 19478.81 & 14600.77 & 0.75 \\
\hline & HPR & Indicator rate, Standard variable bank mortgage rate (\%) & RBA & Sep-85 & Jun-10 & 100 & 5.80 & 17.00 & 9.69 & 3.42 & 0.35 \\
\hline & DTA & Housing debt-to-housing assets (leverage) (\%) & RBA & Sep-85 & Jun-10 & 100 & 10.28 & 31.10 & 18.90 & 6.20 & 0.33 \\
\hline & RTD & Housing interest payments-to-disposable income (debt servicing) (\%) & RBA & Sep-85 & Jun-10 & 100 & 4.02 & 11.19 & 6.05 & 1.86 & 0.31 \\
\hline & INB & Yield on indexed bonds (\%) & RBA & Sep-85 & Jun-10 & 100 & 2.15 & 5.94 & 3.96 & 1.09 & 0.28 \\
\hline & MHP & Median housing price $(\$)$ & ABS & Sep-85 & Jun-10 & 100 & 65900.00 & 534800.00 & 210797.50 & 126634.77 & 0.60 \\
\hline & INC & Annual full-time earnings (\$) & ABS & Sep-85 & Jun-10 & 100 & 20191.60 & 65114.40 & 39224.64 & 12305.59 & 0.31 \\
\hline \multirow{7}{*}{ 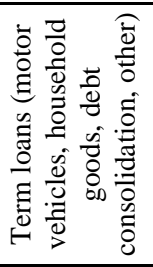 } & TLN & Lending commitments fixed term credit (\$m) & ABS & Dec-88 & Jun-10 & 87 & 2875.57 & 11815.62 & 6237.45 & 2377.77 & 0.38 \\
\hline & TPR & Indicator rate fixed term loans, $(\%)$ & RBA & Dec-88 & Jun-10 & 87 & 10.90 & 20.70 & 13.86 & 2.79 & 0.20 \\
\hline & RET & Retail trade $(\$ \mathrm{~m})$ & ABS & Dec-88 & Jun-10 & 87 & 25422.90 & 59707.00 & 40144.26 & 11142.03 & 0.28 \\
\hline & MVS & Motor vehicle sales (000s) & ABS & Dec-88 & Jun-10 & 87 & 127.98 & 271.26 & 194.53 & 43.64 & 0.22 \\
\hline & CMS & Westpac-Melbourne Institute consumer sentiment index (n) & MI & Dec-88 & Jun-10 & 87 & 67.36 & 123.02 & 101.07 & 13.06 & 0.13 \\
\hline & INB & Yield on indexed bonds (\%) & RBA & Dec-88 & Jun-10 & 87 & 2.15 & 5.63 & 3.77 & 1.04 & 0.28 \\
\hline & INC & Annual full-time earnings (\$) & ABS & Dec-88 & Jun-10 & 87 & 25162.80 & 65114.40 & 41738.79 & 11174.13 & 0.27 \\
\hline \multirow{7}{*}{ 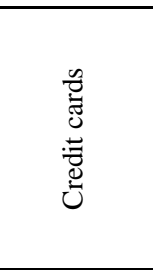 } & CCS & Credit used at end of quarter $(\$ \mathrm{~m})$ & ABS & Mar-90 & Jun-10 & 82 & 33879.81 & 368573.18 & 163724.82 & 119967.34 & 0.73 \\
\hline & ССР & Indicator rate standard credit cards (\%) & RBA & Mar-90 & Jun-10 & 82 & 14.40 & 23.50 & 17.56 & 2.45 & 0.14 \\
\hline & $\mathrm{CPR}$ & Credit limit at end of quarter ( $\$ \mathrm{~m})$ & ABS & Mar-90 & Jun-10 & 82 & 25955.25 & 292915.02 & 122170.11 & 89267.21 & 0.73 \\
\hline & RET & Retail trade $(\$ \mathrm{~m})$ & ABS & Mar-90 & Jun-10 & 82 & 26203.00 & 59707.00 & 41013.05 & 10886.08 & 0.27 \\
\hline & CMS & Westpac-Melbourne Institute consumer sentiment index (n) & MI & Mar-90 & Jun-10 & 82 & 67.36 & 123.02 & 102.00 & 12.58 & 0.12 \\
\hline & INB & Yield on indexed bonds (\%) & RBA & Mar-90 & Jun-10 & 82 & 2.15 & 5.63 & 3.73 & 1.05 & 0.28 \\
\hline & INC & Annual full-time earnings (\$) & ABS & Mar-90 & Jun-10 & 82 & 27227.20 & 65114.40 & 42696.82 & 10787.90 & 0.25 \\
\hline \multirow{8}{*}{ 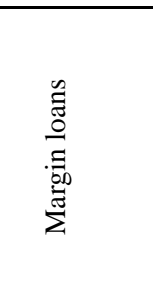 } & MLN & Margin lending $(\$ \mathrm{~m})$ & RBA & Sep-00 & Jun-10 & 40 & 6739.00 & 37767.00 & 18284.55 & 8774.42 & 0.48 \\
\hline & MPR & Indicator rate margin loans (\%) & RBA & Sep-00 & Jun-10 & 40 & 7.00 & 10.50 & 8.37 & 0.86 & 0.10 \\
\hline & PRP & Proportion of protected margin lending (p) & RBA & Sep-00 & Jun-10 & 40 & 0.04 & 0.15 & 0.08 & 0.02 & 0.32 \\
\hline & PLA & Proportion of lending-to-aggregate credit limit (p) & RBA & Sep-00 & Jun-10 & 40 & 0.32 & 0.80 & 0.50 & 0.10 & 0.21 \\
\hline & PAS & Proportion of aggregate credit limit-to-value of underlying security (p) & RBA & Sep-00 & Jun-10 & 40 & 0.63 & 1.54 & 0.90 & 0.18 & 0.20 \\
\hline & ASX & ASX All Ordinaries Index (\%) & ASX & Sep-00 & Jun-10 & 40 & 2778.90 & 6492.40 & 4167.57 & 1050.24 & 0.25 \\
\hline & INB & Yield on indexed bonds (\%) & RBA & Sep-00 & Jun-10 & 40 & 2.15 & 3.62 & 2.87 & 0.46 & 0.16 \\
\hline & INC & Annual full-time earnings (\$) & ABS & Sep-00 & Jun-10 & 40 & 41246.40 & 65114.40 & 52112.06 & 7000.68 & 0.13 \\
\hline
\end{tabular}


TABLE 2. Optimal lag and unit root test results

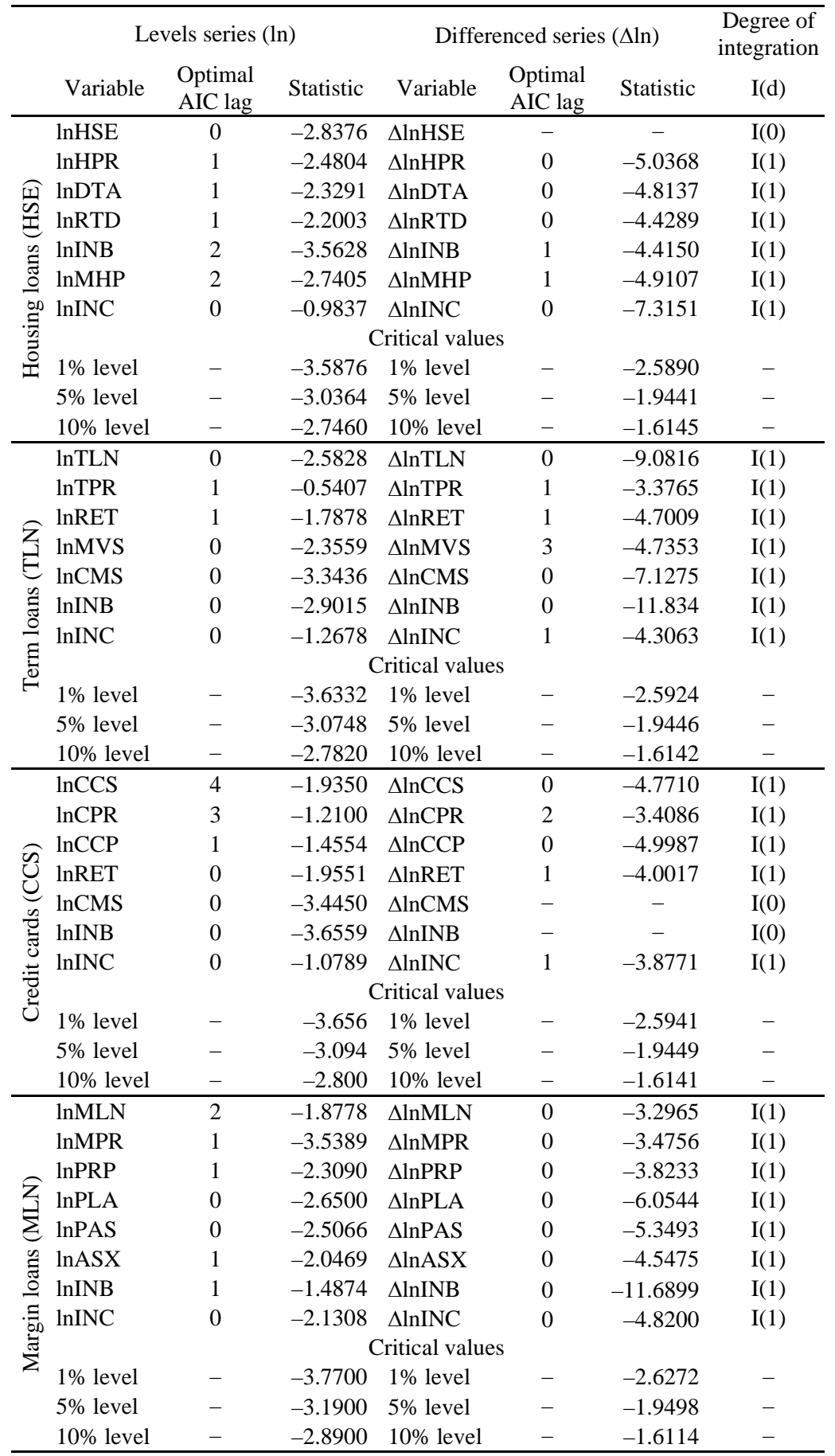


TABLE 3. Estimated long- and short-run models

\begin{tabular}{|c|c|c|c|c|c|c|c|c|c|}
\hline & & Long run & & & & & ort run & & \\
\hline & Variable & Coef. & Std. err. & $\mathrm{p}$-value & & Variable & Coef. & Std. err. & p-value \\
\hline & CONS. & -6.0321 & 2.2608 & 0.0091 & & CONS. & 0.0346 & 0.0249 & 0.1685 \\
\hline & $\operatorname{lnHSE}(-1)$ & 0.6940 & 0.0731 & $<0.0001$ & & $\Delta \operatorname{lnHSE}(-1)$ & 0.3996 & 0.1712 & 0.0219 \\
\hline 鹠 & $\operatorname{lnHPR}(-1)$ & -0.1326 & 0.1755 & 0.4522 & 됭 & $\Delta \operatorname{lnHPR}(-1)$ & -0.1857 & 0.2211 & 0.4033 \\
\hline 壱 & GFC $\times \ln H P R(-1)$ & -0.2476 & 0.1616 & 0.1290 & 胥 & $\begin{array}{l}\text { GFC } \times \Delta \ln H P R(- \\
\text { 1) }\end{array}$ & -0.1460 & 0.2326 & 0.5319 \\
\hline$\frac{\pi}{20}$ & $\operatorname{lnDTA}(-1)$ & -0.1971 & 0.1676 & 0.2430 & نِ & $\Delta \operatorname{lnDTA}(-1)$ & -0.2847 & 0.5172 & 0.5834 \\
\hline ) & $\ln \operatorname{RTD}(-1)$ & 0.1273 & 0.1966 & 0.5191 & 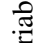 & $\Delta \ln \mathrm{RTD}(-1)$ & -0.5302 & 0.2856 & 0.0668 \\
\hline$=$ & $\ln I N B(-1)$ & -0.2730 & 0.0815 & 0.0012 & సี & $\Delta \ln I N B(-1)$ & -0.3275 & 0.0944 & 0.0008 \\
\hline ष्ల & $\operatorname{lnMHP}(-1)$ & -0.4429 & 0.1810 & 0.0164 & 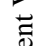 & $\Delta \ln M H P(-1)$ & -0.1650 & 0.2209 & 0.4571 \\
\hline ฮี & $\ln I N C(-1)$ & 1.4578 & 0.3551 & $<0.0001$ & تี & $\Delta \operatorname{lnINC}(-1)$ & -0.6392 & 1.6853 & 0.7054 \\
\hline صั & GFC $\times \ln I N C(-1)$ & -1.1947 & 1.1089 & 0.2842 & 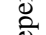 & $\mathrm{GFC} \times \Delta \ln \operatorname{INC}(-1)$ & -3.0480 & 2.4312 & 0.2133 \\
\hline & GFC & 13.5316 & 12.4544 & 0.2802 & ص & $\operatorname{EHSE}(-1)$ & -0.6887 & 0.1759 & 0.0002 \\
\hline & R-squared & 0.9917 & - & - & & R-squared & 0.4105 & - & - \\
\hline & F-statistic & 1055.1930 & - & $<0.0001$ & & F-statistic & 6.0580 & - & $<0.0001$ \\
\hline & CONS. & 0.7699 & 1.2639 & 0.5443 & & CONS. & 0.0001 & 0.0163 & 0.9975 \\
\hline & $\operatorname{lnTLN}(-1)$ & 0.7253 & 0.0888 & $<0.0001$ & & $\Delta \operatorname{lnTLN}(-1)$ & 0.5073 & 0.2007 & 0.0136 \\
\hline z & $\operatorname{lnTPR}(-1)$ & -0.1937 & 0.0986 & 0.0531 & z & $\Delta \operatorname{lnTPR}(-1)$ & -0.0045 & 0.2270 & 0.9841 \\
\hline 当 & $\begin{array}{l}\text { GFC } \times \ln T P R(- \\
\text { 1) }\end{array}$ & 0.1658 & 0.1915 & 0.3892 & 宣 & $\mathrm{GFC} \times \Delta \ln \mathrm{TPR}(-1)$ & -1.2582 & 0.7394 & 0.0931 \\
\hline$\ddot{\circ}$ & $\operatorname{lnRET}(-1)$ & 0.6465 & 0.4194 & 0.1275 & $\ddot{\ddot{g}}$ & $\Delta \operatorname{lnRET}(-1)$ & 1.5132 & 0.5222 & 0.0050 \\
\hline . & $\operatorname{lnMVS}(-1)$ & -0.1892 & 0.1634 & 0.2505 & 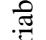 & $\Delta \operatorname{lnMVS}(-1)$ & -0.3874 & 0.2483 & 0.1231 \\
\hline$>^{\pi}$ & $\operatorname{lnCMS}(-1)$ & 0.0922 & 0.0803 & 0.2544 & กี & $\Delta \operatorname{lnCMS}(-1)$ & 0.1006 & 0.0695 & 0.1524 \\
\hline 菅 & $\ln I N B(-1)$ & -0.1005 & 0.0533 & 0.0632 & 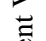 & $\Delta \ln I N B(-1)$ & -0.1592 & 0.0678 & 0.0217 \\
\hline $\bar{\sigma}$ & $\ln I N C(-1)$ & -0.3781 & 0.3559 & 0.2915 & تृ & $\Delta \ln I N C(-1)$ & -0.7567 & 1.1451 & 0.5108 \\
\hline 完 & GFC $\times \ln I N C(-1)$ & 1.3713 & 0.6077 & 0.0270 & 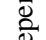 & $\mathrm{GFC} \times \Delta \ln I N C(-1)$ & 2.1382 & 1.4488 & 0.1443 \\
\hline & GFC & -15.4608 & 6.5891 & 0.0216 & ด̆ & $\operatorname{ETLN}(-1)$ & -0.7456 & 0.2254 & 0.0015 \\
\hline & R-squared & 0.9841 & - & - & & R-squared & 0.3173 & - & - \\
\hline & F-statistic & 458.3739 & - & $<0.0001$ & & F-statistic & 3.3923 & - & $<0.0001$ \\
\hline & CONS. & -9.9418 & 18.9023 & 0.6006 & & CONS. & -0.0100 & 0.0056 & 0.0781 \\
\hline$\infty$ & $\operatorname{lnCCS}(-1)$ & -1.0305 & 0.0259 & $<0.0001$ & 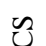 & $\Delta \operatorname{lnCCS}(-1)$ & -0.6137 & 0.10331 & $<0.0001$ \\
\hline Uِ & $\operatorname{lnCPR}$ & -0.4451 & 0.7734 & 0.5667 & U & $\triangle \operatorname{lnCPR}$ & 0.6371 & 0.0821 & $<0.0001$ \\
\hline$\Xi$ & $\mathrm{GFC} \times \ln \mathrm{CPR}$ & -0.1161 & 0.3393 & 0.7331 & 륵 & $\mathrm{GFC} \times \Delta \operatorname{lnCPR}$ & -0.5075 & 0.4947 & 0.3085 \\
\hline$\frac{0}{2}$ & $\operatorname{lnCCP}$ & -0.1724 & 0.0584 & 0.0043 & $\ddot{0}$ & $\Delta \operatorname{lnCCP}$ & 0.0429 & 0.0654 & 0.5134 \\
\hline . & $\operatorname{lnCMS}$ & -0.2035 & 0.2173 & 0.3522 & 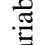 & $\Delta \operatorname{lnCMS}$ & 0.0378 & 0.0258 & 0.1478 \\
\hline$>^{\pi}$ & $\operatorname{lnINB}$ & 0.0315 & 0.0452 & 0.4889 & $\sum^{\text {กี }}$ & $\Delta \ln I N B$ & 0.0353 & 0.0218 & 0.1091 \\
\hline 芑 & $\operatorname{lnINC}$ & 1.5146 & 2.7182 & 0.5791 & 苛 & $\Delta \operatorname{lnINC}$ & 0.2229 & 0.3990 & 0.5782 \\
\hline $\bar{z}$ & GFC $\times \ln I N C$ & -0.6935 & 1.5858 & 0.6632 & ت્ & $\mathrm{GFC} \times \Delta \ln I N C$ & 0.5448 & 0.6705 & 0.4192 \\
\hline Qें & GFC & 8.9586 & 15.2075 & 0.5577 & 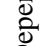 & $\operatorname{ECCS}(-1)$ & -0.7047 & 0.1573 & $<0.0001$ \\
\hline & R-squared & 0.9993 & - & - & คั & R-squared & 0.6459 & - & - \\
\hline & F-statistic & 11692.5200 & - & $<0.0001$ & & F-statistic & 14.1921 & - & $<0.0001$ \\
\hline & CONS. & -25.1196 & 5.1532 & $<0.0001$ & & CONS. & 0.0145 & 0.0125 & 0.2563 \\
\hline & $\operatorname{lnMLN}(-1)$ & 0.3426 & 0.1170 & 0.0069 & & $\Delta \ln M L N(-1)$ & 0.1468 & 0.0879 & 0.1069 \\
\hline Z & $\operatorname{lnMPR}$ & -0.4176 & 0.2032 & 0.0497 & Z & $\triangle \operatorname{lnMPR}$ & -0.2109 & 0.1896 & 0.2763 \\
\hline$\dot{z}$ & GFC $\times \ln M P R$ & 0.1919 & 0.1653 & 0.2558 & $\sum$ & $\mathrm{GFC} \times \Delta \ln M P R$ & 0.4052 & 0.2196 & 0.0764 \\
\hline$\underline{E}$ & $\ln P R P$ & 0.0140 & 0.0764 & 0.8556 & $\stackrel{\Xi}{\triangleleft}$ & $\Delta \ln P R P$ & 0.1205 & 0.0533 & 0.0325 \\
\hline نِ & $\ln P L A$ & 0.8333 & 0.2231 & 0.0009 & ن̈ & $\Delta \operatorname{lnPLA}$ & 0.8004 & 0.1092 & $<0.0001$ \\
\hline 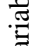 & $\ln P A S$ & 0.4773 & 0.1676 & 0.0083 &.$\overline{0}$ & $\triangle \ln P A S$ & 0.3869 & 0.0923 & 0.0003 \\
\hline$\overbrace{}^{\pi}$ & $\ln A S X$ & 0.7390 & 0.1613 & 0.0001 & $\stackrel{\pi}{>}$ & $\Delta \ln A S X$ & 0.6878 & 0.0895 & $<0.0001$ \\
\hline $\overrightarrow{0}$ & $\operatorname{lnINB}$ & 0.0151 & 0.0762 & 0.8445 & $=$ & $\Delta \operatorname{lnINB}$ & 0.0093 & 0.0392 & 0.8150 \\
\hline $\bar{\Xi}$ & $\operatorname{lnINC}$ & 2.4868 & 0.5461 & $<0.0001$ & تี & $\Delta \operatorname{lnINC}$ & 2.0180 & 1.0171 & 0.0579 \\
\hline Qे & GFC $\times \operatorname{lnINC}$ & -3.5596 & 0.8087 & 0.0002 & . & $\mathrm{GFC} \times \Delta \ln I N C$ & -5.0007 & 1.0273 & $<0.0001$ \\
\hline & GFC & 38.5986 & 8.8458 & 0.0002 & ดั & EMLN(-1) & -1.1279 & 0.1829 & $<0.0001$ \\
\hline & R-squared & 0.9972 & - & - & & R-squared & 0.9465 & - & - \\
\hline & F-statistic & 875.2317 & - & $<0.0001$ & & F-statistic & 41.7932 & - & $<0.0001$ \\
\hline
\end{tabular}

